\title{
Low-energy Grubbing for Control of Junipers
}

\author{
H.T. WIEDEMANN AND B.T. CROSS
}

\begin{abstract}
Low-energy grubbing was effective and economical in controlling sparse to moderate stands of junipers infesting rangeland. $A$ small, 48.5-kW (65-hp), shift-on-the-go crawler tractor, as compared to tractors larger than $74.5 \mathrm{~kW}$ (100-hp) normally used, was adapted for grubbing by attaching a $U$-shape blade to the front mounted C-frame for root cutting at depths of 15 to $30 \mathrm{~cm}$. A $98 \%$ plant kill was achieved because uprooting of trees below the budzone prevented sprouting. The newly designed hydraulic attachment significantly improved tree uprooting. Grubbing rate was a curvilinear function of juniper density and varied approximately from 4.0 to $0.5 \mathrm{ha} / \mathrm{hr}(10$ to $1.25 \mathrm{ac} / \mathrm{hr})$ to remove 80 to 500 trees/ha (30 to 200 trees/acre). Cost varied from $\$ 6.00$ to $\$ 50.00 /$ ha $(\$ 2.40$ to $\$ 20.00 /$ acre $)$.
\end{abstract}

Mixed stands of redberry and ashe juniper (Juniperus pinchoti Sudw. and Juniperus ashei Buchholz) infest approximately 7.6 million ha of Texas grassland (Soil Conservation Service 1973). Control of these invaders is a major concern of ranchmen in the Rolling Plains, Edwards Plateau, and Cross Timbers and Prairies vegetational areas. The rapid spread of juniper, 1.4 million ha increase between 1948 and 1963 (Smith and Rechenthin 1964), has been attributed mainly to birds and rodents (Phillips 1910). Juniper stands rapidly increase in density and soon reduce grass cover and hamper livestock operations (Smith and Rechenthin 1964). Robison and Cross (1970) determined that control of dense stands of junipers increased oven-dried forage production from 410 to $1,547 \mathrm{~kg} / \mathrm{ha}$ in the Edwards Plateau.

Grubbing and chaining are the principal methods of control; however, hand cutting was widely used in the 1930's for control of ashe juniper. Chaining is very economical but results vary from fair to good control. Chaining is most effective on large trees in loose, shallow, or moist soils where trees are easily uprooted, or in stands of ashe juniper (Rechenthin et al. 1964). Control of ashe juniper is relatively easy since there are no buds on the trunk and regrowth does not occur when all green limbs are removed. Redberry juniper, however, will resprout unless the entire stump is severed below the bud-zone, which occurs near groundline (Wolff 1948).

Power grubbing involves uprooting of trees with a U-shape blade attached to the front mounted C-frame of a crawler tractor. The technique is also referred to as "dozing" or "bulldozing". Dozing normally indicates that a small $U$-shape blade is attached to the bulldozer blade for uprooting or the bulldozer alone is used to shear the plant at ground line.

Power grubbing for brush control with a bulldozer was introduced in 1938 by a North Texas ranchman (Dickson et al. 1940). To improve the percentage of trees killed, a "stinger" was developed, in cooperation with the Texas Agricultural Experiment

\footnotetext{
Authors are associate professor and research associate, Texas Agricultural Experiment Station, P.O. Box 1658, Vernon, Texas 76384.

The report approved as Technical Article TA-15494 from the Texas Agricultural Experiment Station.

Mention of trade name is for identification only and does not imply an cndorsement or preference over other products not mentioned.

Acknowledgement: The authors are appreciative for the excellent cooperation and financial support provided in part by Tarleton State University, Stephenville; Brush Control and Range Improvement Assn., Abilene; Garyln Hoffman, Texas Agricultural Extension Service, College Station; and the Soil Conservation Service, Stephenville.

Manuscript received September 1979.
}

Station, which attached to the bulldozer blade and severed the stump below ground with less soil disturbance. Refinements have resulted in the present day, U-shaped blade attached directly to front mounted C-frames on $74.6 \mathrm{~kW}(100 \mathrm{hp})$ or larger crawler tractors. They operate efficiently in sparse to moderate stands of large trees at a rate of 0.4 to $1.2 \mathrm{ha} / \mathrm{hr}$ (Fisher et al. 1959, Wiedemann 1971).

More recently, low-energy grubbing with a $48.5-\mathrm{kW}(65-\mathrm{hp})$ crawler tractor has resulted in a highly efficient method for controlling small mesquite trees (Prosopis glandulosa Torr. var. glandulosa) Wiedemann et al. 1977). It averaged from 1 to $4 \mathrm{ha} / \mathrm{hr}$ in densities of 80 to 250 trees/ha and was more economical than a $89.5-\mathrm{k} \mathrm{W}(120-\mathrm{hp})$ unit. A unique, hydraulically controlled blade angle adjustment was developed to split stumps or loosen the roots which increase tree-size grubbing capacity by at least $1 / 3$ (Wiedemann et al. 1977, Wiedemann et al. 1978). Low-energy grubbing has also been effective and economical in controlling moderate stands of huisache (Acacia farnesiana (L.) Willd.) (Bontrager et al. 1979).

Sparse to moderate stands of juniper appear well suited to low-energy grubbing technique of control. The objectives of this study were to (1) determine the per-hr grubbing rates and costs for various juniper densities, (2) determine plant kill effectiveness, and (3) evaluate performance between standard and hydraulic grubbers.

\section{Materials and Equipment}

\section{Research Site}

The study area was located on Tarleton State University's Hunnewell Ranch, east of Stephenville, in the Cross Timbers and Prairies vegetational area of Texas. Soils were classified as Maloterre or Purves-Dugout complex. These shallow, calcareous, gravely, clay to clay loam textured soils were underlain with a limestone layer 10 to $30 \mathrm{~cm}$ below the surface. Outcropping of the limestone layer often gave a distinct benched or stairstep appearance to the area. Juniper densities range from 50 to 600 plants/ha on these soils with trees ranging from 0.3 to $5 \mathrm{~m}$ tall. Sparse stands ( $<250$ trees/ha) of trees 0.3 to $1.8 \mathrm{~m}$ tall are more prevalent on the shallower Maloterre soil. A moderately deep Windthorst fine sandy loam site supporting a sparse stand was also selected to represent infestations in improved pastures. Both redberry and ashe juniper were present on each soil site.

\section{Low-Energy Grubber}

A John Deere 450-B, turbocharged, shift-on-the-go, 48.5-kW 65-hp) crawler tractor with an outside-mounted angle dozer (no. 6410) and ROPS canopy (Roll-Over Protection Structure) with brush protection option was adapted for grubbing (Fig. 1). The sharp, U-shape blade was designed for root severing at 15 to $30 \mathrm{~cm}$ below ground. The special hydraulic attachment utilized two, 8.9$\mathrm{cm}$ diameter, $25.4-\mathrm{cm}$ stroke, double-acting cylinders to rotate the cutting blade approximately 70 degrees (Fig. 2). The unit was labeled "hydraulic"grubber for identification. A second grubber of the same size and shape without the hydraulic blade-angle adjustment was utilized and labeled "standard" grubber. Further grubber details are outlined by Wiedemann et al. (1977). Tractor cost of 


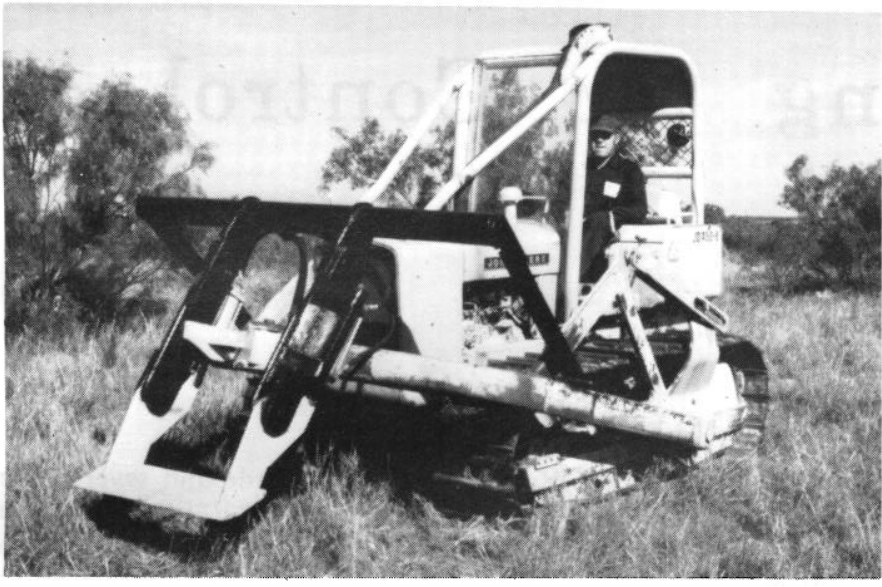

Fig. 1. Low-energy grubber developed by Texas Agricultural Experiment Station engineers to control small trees infesting rangeland. The small, $48,5-k W(65-h p)$, crawler tractor was adapted for grubbing by attaching special $U$-shaped blade to the front mounted $C$-frame.

$\$ 25.00 / \mathrm{hr}$ was based on normal charges by reputable conservation contractors for small crawlers during 1979. Charges were $\$ 15.00 / \mathrm{hr}$ in 1974 when this study was conducted.

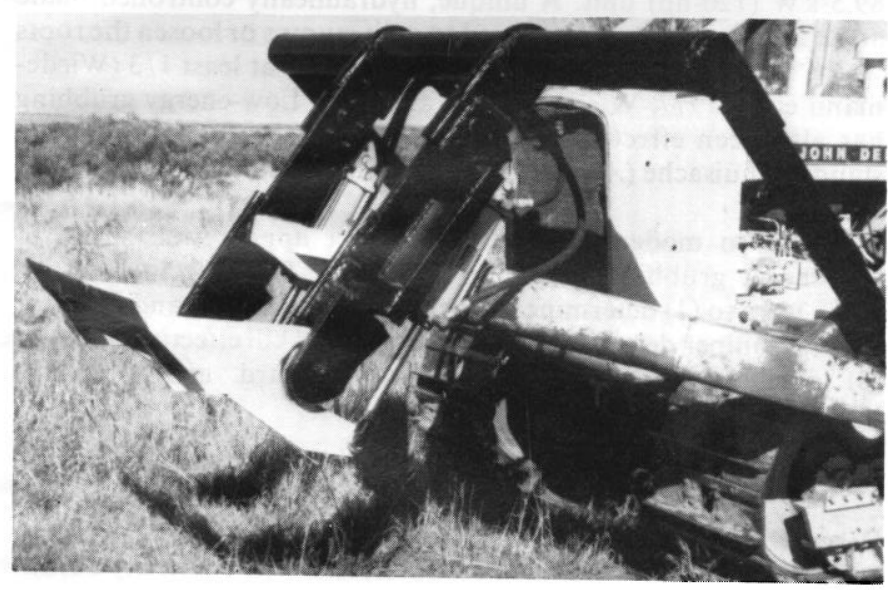

Fig. 2. Unique hydraulic attachment increases tree size uprooting capacity of low-energy grubber. Blade rotation of $70^{\circ}$ results from extending the hydraulic cylinders and action aids in tearing roots loose and stump uprooting.

\section{Experimental Procedure}

Junipers were grubbed from 20, 1- to 5-ha plots during January 1974. Plot size was varied to assure at least 1 hour of grubbing time per plot. An operator-activated counter was attached to grubber controls for tree counting, and clock time was recorded before and after grubbing each plot. The same tractor and operator were utilized in all tests. Plant mortalities were determined 20 months following treatment. Counts of live, dead, and new seedling plants were taken in $1.8-\mathrm{m}$ belt transects from each plot.

Regression analysis was applied to evaluate the relationship between grubbing time (dependent variable) and juniper density (independent variable). Highest correlation coefficient $(r)$ was used to determine the best-fit relationship between linear and curvilinear (exponential) regression lines. Difference between grubbers was statistically evaluated by contrasting regression line slopes with a $t$-test.

\section{Results and Discussion}

Low-energy grubbing was highly effective in cont rolling juniper with plant kills averaging $98 \%$. Those plants which resprouted were not severed below the bud-zone because large fragments of limestone had prevented complete plant uprooting.

Sparse to moderate infestations averaging 259 junipers/ha were grubbed at a rate $2.0 \mathrm{ha} / \mathrm{hr}$ and cost $\$ 12.50 /$ ha. The average grubbing rate increased to $3.0 \mathrm{ha} / \mathrm{hr}$ in the sparse stands averaging $143 \mathrm{tree} / \mathrm{ha}$ but decreased to $0.8 \mathrm{ha} / \mathrm{hr}$ in moderate stands averaging 400 tree $/$ ha. A significant $(P<0.01)$ correlation $(r=0.96$, d.f. 9$)$ existed between plant densities of 79 to 531 trees/ha (X) and grubbing rate $(Y)$ when data was fitted to the curvilinear equation illustrated in Figure 3.

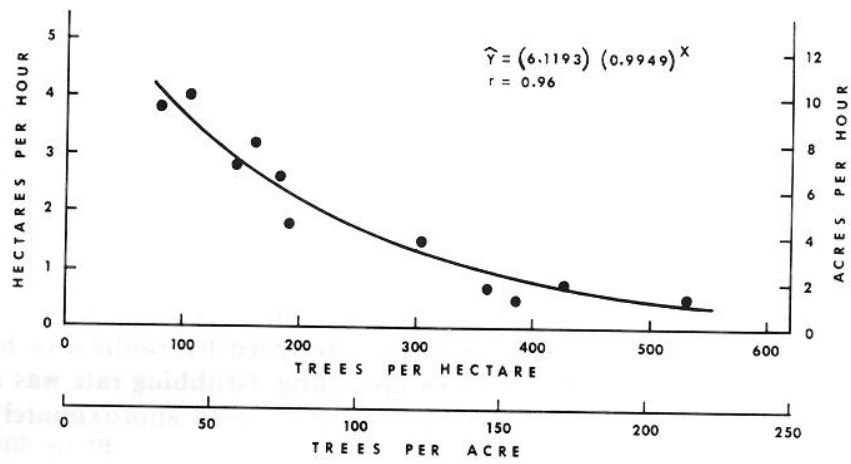

Fig. 3 Per-hour performance $(Y)$ of low-energy grubber in various densities $(X)$ of juniper trees 0.3-to 1.8-m tall; $\hat{Y}$, X based on per-hectare units.

Because of the underlying layer of limestone, junipers were all shallow rooted, and thus uprooting was simplified. This was especially true with large trees since the limestone layer acted as a footing for hydraulically activated blade rotation. After the blade was initially embedded in the base of the stump near the limestone layer, blade rotation effectively raised the stump from the soil. The number of trees grubbed $/ \mathrm{min}(\mathrm{Y})$ by the hydraulic grubber remained at a higher level of performance than the standard unit as juniper densities (X) increased from 213 trees/ha (Fig. 4) and regression-line slopes were significantly different $(P<0.025)$. Since the hydraulic mechanism was not activated while grubbing junipers less than $1.2 \mathrm{~m}$ tall, its value will be more evident when trees are consistently larger. Additional analysis of the hydraulically assisted grubbing technique is covered by Wiedemann et al. (1978).

The numerous, small fragments (less than $10-\mathrm{cm}$ long) of limestone encountered in the top soil did not deter blade penetration or grubbing action. In isolated cases, fragments were larger than 30 $\mathrm{cm}$ and these hampered uprooting. Fracturing of the limestone layer was not necessary for plant uprooting and should be avoided to prevent undue mechanical damage to the grubber. Shields on the grubber frame (Fig. 2) were necessary to prevent tree limbs from breaking the hydraulic hose fitting on the cylinders.

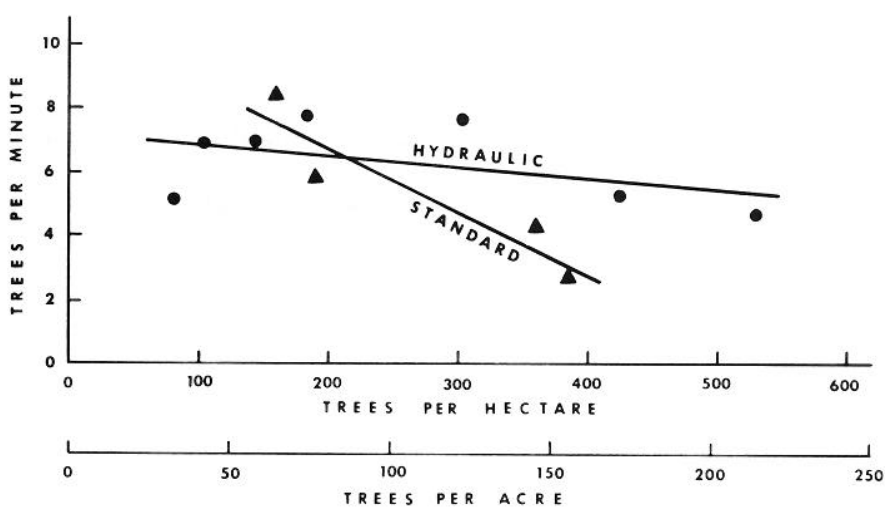

Fig. 4. Trees/min grubbing rates $(Y)$ for hydraulic and standard grubbers in various juniper densities $(X)$. Regression-lines slopes were significantly different $(\mathrm{P}<0.025)$ and the hydraulic grubber maintained a higher level of performance above 213 trees/ha. 
Table 1. Low-energy grubbing of junipers under broad range of conditions near Stephenville, Tex.

\begin{tabular}{|c|c|c|c|c|}
\hline $\begin{array}{l}\text { Tree } \\
\text { height }(\mathrm{m}) \text { Soil condition }\end{array}$ & No. tests & Trees/ha & $\mathrm{Ha} / \mathrm{hr}$ & $\$ / h^{1}$ \\
\hline $\begin{array}{c}0.3 \text { to } 1.85 \text { to } 20 \mathrm{~cm} \text { of soil } \\
\text { over layer of lime- } \\
\text { stone }\end{array}$ & 11 & 259 & 2.0 & 12.50 \\
\hline $\begin{array}{c}1.8 \text { to } 3.010 \text { to } 15 \mathrm{~cm} \text { of soil } \\
\text { over layer of lime- } \\
\text { stone }\end{array}$ & 4 & 54 & 1.8 & 13.88 \\
\hline 1.0 to 1.8 deep sandy loam & 1 & 207 & 4.0 & 6.25 \\
\hline
\end{tabular}

'Data based on $\$ 25.00 / \mathrm{hr}$ contract tractor cost.

A potpourri of field tests with the hydraulic grubber were conducted to detect conditions where the prediction equation would be invalid. Data are presented in Table 1, and point out the need for additional research where trees are usually large or where soil conditions are favorable for much faster tractor speeds.

Predicted grubbing costs varied from $\$ 6.00$ to $\$ 50.00 /$ ha in the range of densities grubbed. The exponential cost curve is presented in Figure 5 using a contract tractor cost of $\$ 25.00 / \mathrm{hr}$. All per-hour grubbing rates represent maximum rates for short periods; therefore, a 75 to $85 \%$ field efficiency factor would be anticipated in commercial operation.

The low-energy grubbing technique appears well suited to controlling junipers 1- to 2-m tall in sparse to moderate stands. Although percentage kill of original plants was high, an average of 230 seedling/ha were observed 20 months following treatment. The original infestation averaged 254 plants/ha. Thus, follow-up treatment will be necessary in the future. Additional research to develop a rubber-tire tractor grubbing technique as a low-cost maintenance-type control practice for these small trees $(<1.25 \mathrm{~m}$ tall) appears feasible.

\section{Literature Cited}

Bontrager, O.E., C.J. Scifres, and D.L. Drawe. 1979. Huisache control by power grubbing. J. Range Manage. 32:185-188.

Dickson, R.E., B.G. Langley, and C.E. Fisher. 1940. Water and soil conservation experiments at Spur, Tex. Texas Agr. Exp. Sta. B-587:35.

Fisher, C.E., C.H. Meadors, R. Behrens, E.D. Robison, P.T. Marion, and C.H. Morton. 1959. Control of mesquite on grazing lands. Texas Agr.

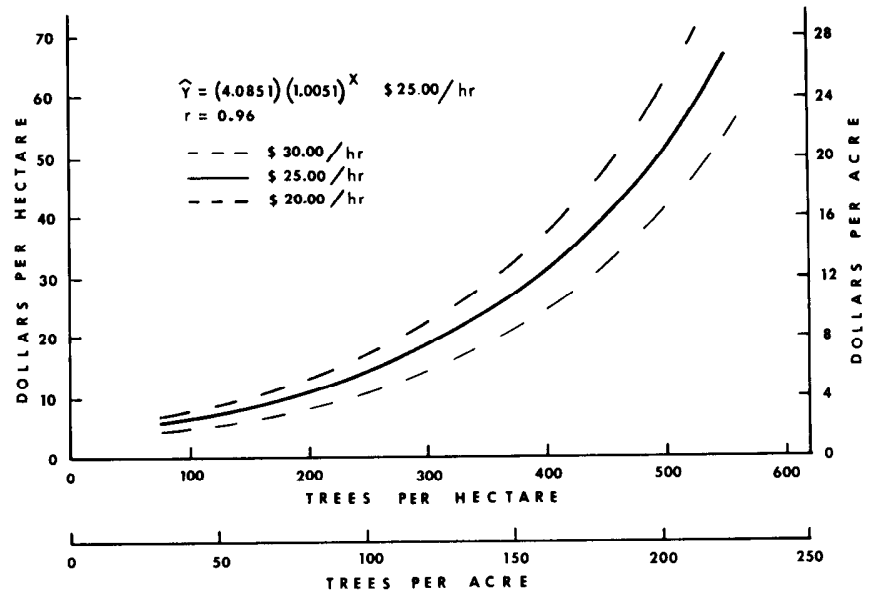

Fig. 5. Per-hectare and per-acre cost ( $Y)$ of low-energy grubbing at various density of junipers $(X)$ 0.3- to 1.8-m tall based on a contract cost of $\$ 25.00 / \mathrm{hr}$. Since tractor costs often vary, rates of $\$ 20.00$ and $\$ 30.00 / \mathrm{hr}$ are also illustrated. $\hat{Y}, X$ are based on metric units.

Exp. Sta. B-935:5.

Phillips, F.J. 1910. The dissemination of junipers by birds. Forestry Quart. 8:60-73

Rechenthin, C.A., H.M. Bell, R.J. Pederson, and D.B. Polk. 1964. Grassland restoration part II-Brush control. USDA, SCS, Temple, Tex. p. 8.

Robison, E.D., and B.T. Cross. 1970. Redberry juniper control and grass response following aerial application of picloram. Texas Agr. Exp. Sta., PR-2805 In: Consolidated PR-2801-2828:20.

Smith, H.N., and C.A. Rechenthin. 1964. Grassland restoration-The problem. USDA, SCS, Temple, Tex.

Soil Conservation Service. 1973. Acres of grassland infested in woody species-1973 survey. USDA, SCS, Temple, Tex.

Wiedemann, H.T. 1971. Mechanical brush control practices usd in Texas. Amer. Soc. Agr. Eng. Southwest Region Pap. No. 71-106, Sequoyah State Park, Okla. April.

Wiedemann, H.T., B.T. Cross, and C.E. Fisher. 1977. Low-energy grubber for controlling brush. Transaction of the Amer. Soc. Agr. Eng. 20:210213.

Wiedemann, H.T., J.E. Slosser, and B.T. Cross. 1978. Amer. Soc. Agr. Eng. Paper No. 78-1571, Chicago, Ill., Transaction of the Amer. Soc. Agr. Eng. 22:1276-1278. 1979.

Wolff, S.E. 1948. An evaluation of some weedy Texas junipers. USDA, SCS, Ft. Worth, Tex. p. 5-7.

\section{Call For Papers}

Titles and abstracts of volunteer papers for the 1982 Annual Meeting of the Society for Range Management in Calgary are due August 15, 1981. For additional information, see p. 160, March Journal of Range Management, or the inside front cover, April Rangelands. Send titles and abstracts to: Alex Johnston, c/o Lands Division, AENR, Sun Center, 530 8th St. South, Lethbridge, Alta., Canada $T 1 / 2 / 8$. 